\title{
鋼繊維補強コンクリートオーバーレイの設計に関する基礎的研究
}

\section{FUNDAMENTAL STUDIES ON STEEL FIBER REINFORCED CONCRETE OVERLAY DESIGN}

\author{
國 分 修一* · 伊吹山四郎** ・ 瀬 戸 薫*** \\ By Shuichi KOKUBU, Shiro IBUKIYAMA and Kaoru SETO
}

\begin{abstract}
The use of steel fibre-reinforced concrete (SFRC) immune to rutting and distortion would provide excellent, smooth and durable overlays on the existing asphalt pavements. This paper aims to find a way of mechanical analysis of the SFRC overlay system and to set up a design method of the SFRC overlay slab thickness.

According to model and full scale loading test, it clearly appears that the SFRC overlay system has a great deal of resistance against actual traffic loads and can be presumed as a multilayered composit pavement which regard the existing asphalt pavement as a part of SFRC slab, and it is further shown that the "yield-line theory" can be applied basically to the design method of slab thickness.
\end{abstract}

\section{1. まえがき}

わが国の主要道路における交通は量および質ともに大 きく, アスファルト舗装の多くは流動によるわだち変形 を起こしているか, また積雪寒冷地にあっては摩耗によ る変形を起こしている。このような路面の変形は交通の 安全走行を損ない, 騒音や振動などの環境公害の原因之 もなるので, 著しい路面の変形は平坦に修繥する必要が ある. しかし, 歴青系材料を用いて修繕する場合, 路面 の変形問題を全面的に解決することはきわめて難しく, 舗装の修繥は頻繁に実施する必要がある.このため, 路 面を平坦に保つ耐久的な補修材料を開発することが道路 舗装における緊急かつ重要な課題となっている.

一方, 昭和 49 年頃からわが国でも鋼瀻維補強コンク リートが研究され始め, 普通コンクリートに比べてひび われ発生に対する抵抗性が著しく大きく, また引張強度, 曲げ強度, せん断強度の増大, 靱性, 耐衝撃性, 曲げ疲 労性状の向上など優れた特性を有していることが明らか となってきた1) 3). したがって, 鋼繊維補強コンクリー

* 正会員 工修 大林道路(株)技術研究所 ( 污336 浦和市沼影 2-12-36)

** 正会員 工博 大林道路 (株)専務取締役 ( ₹101 千代田区神田錦町 1-2-1)

*** 正会員 大林道路(株)技術部長 (同上)
トは, 重交通の道路, 空港あるいは橋面などの舗装1),4, 特に, 比較的薄層で変形を修繥しなければならないアス ファルト舖装のオーバーレイに用いる場合にはきわめて 有効な材料といえる ${ }^{5), 6}$.

しかし,わが国の場合, オーバーレイの建設は歴青系材 料で行うのが一般的で，ぜい性材料であるコンクリート を比較的薄層で用いることはわが国の特殊な道路事情と 相まってほとんど考慮されたことがなく，またアスファ ルト舗装上のコンクリートオーバーレイの設計方法に関 しても米国における便宜的な手法が紹介されているクに すぎずほとんど検討が加えられていない，特に，鋼䋐維 補強コンクリートオーバーレイの設計に関しては, コン クリート補装上のコンクリートオーバーレイに関しての 経験的な版厚設計式 ${ }^{71,8)}$ を参考にしたオーバーレイ厚の 設計式が提案されている ${ }^{9}$ のみで，アスファルト舗装上 の鋼瀻維補強コンクリートオーバーレイに関する研究は 著しく遅れているのが現状のように思われる.

本研究は上記の事情を考え，アスファルト舗装上の鋼 瀻維補強コンクリートオーバーレイシステムの有効性の 確認とオーバーレイシステムにおけるアスファルト層の 機能の評価およびオーバーレイ厚の設計に関する資料を 得ることを目的に実施したものであり, 供試版と一般道 路における載荷実験の成果, これに基づく基本設計式の 
提案およびその設計式の妥当性の検討を内容としたもの である。

\section{2. 供試版における載荷実験}

\section{（1）実験 概 要}

供試版における載荷実験は，アスファルト舗装上の オーバーレイシステムの耐荷性, 有効性の確認とアス ファルト層の取扱いの検討および基本設計式を考えるう えでの資料を得ることを目標にしている．したがって， 実験では図一 1 に示すような試験舗装を作り，その上に 厚さ $5 \mathrm{~cm}$ で $3 \times 3 \mathrm{~m}$ の大きさの鋼緎維補強コンクリー 卜供試版を表一 1 に組合せを示すとおり合計 16 枚作製 した，舗装の支持力は各層において平板載荷試験によっ て求めており, 值は表一1に示すとおりである.また, 試験舗装の路床は支持力係数が $2.5 \mathrm{kgf} / \mathrm{cm}^{3}$ の関東ロー
ムであったので，支持力を高めるために $30 \mathrm{~cm}$ 石灰で 安定処理した。

載荷実験は，11〜12 月の冬期間に中央部載荷を，7 9 月の夏期に縁部載荷を実施した，供試版表面のひずみ およびたわみは図一 1 に示すように $20 \mathrm{~cm}$ 間隔に測定 しており，このほか，一部の供試版には荷重直下の版底 面に埋込型ひずみゲージを配置しさらに路床および路盤 に土圧計を設置して, 供試版種類, 支持層の違いによる 差を測定した。また，使用した鋼瀻維補強コンクリート の標準養生および現場養生における強度, 弾性係数わよ びポアソン比は表一2に示すとおりである.

\section{（2）供試版のひびわれ，たわみおよび応力}

a) 供試版のひびわれ

供試版のひびわれ発生状況は，版表面に貼付けたひず みゲージと目視により観察した。その一例は図一2に示

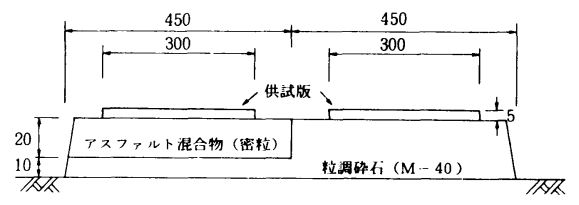

(们灰'定処种) 巣位. $(\mathrm{cm})$
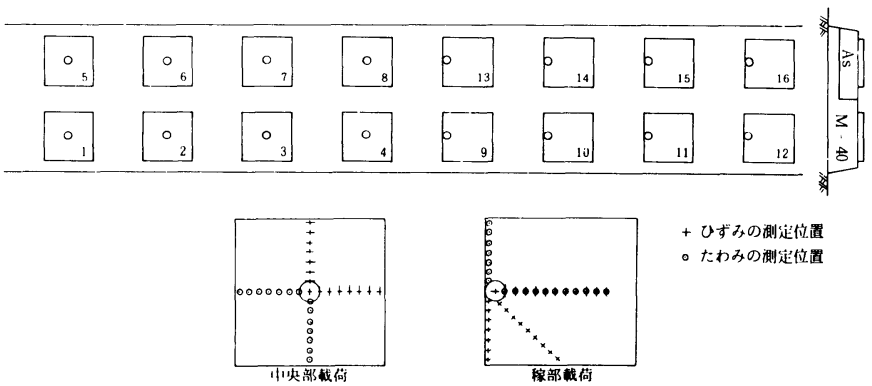

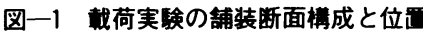

すようである．砕石層上で供試版の中央に 載荷した場合, 普通コンクリート版では最 初に発見した版表面の微小ひびわれが少し の荷重増加で急激に成長し，ほぼ円形のひ びわれが形成され，その直後に放射状のひ びわれが発生して急激に崩壊する（図一2 (a))。これに対し，鋼繊維補強コンクリー 卜版では最初に発見した微小ひびわれの周 辺に新しいひびわれが次々に発生する. 載 荷重を増加させると，それらのひびわれは しだいに成長するが, 成長の停止するもの もかなり認められ，最初に発見したひびわ れが必ずしも成長を続けるとは限らない. また,供試版表面に形成されるひびわれは, ほぼ円形であるがかなり複雑で不連続なも のとなる（図一2 (b)).

アスファルト層上供試版の中央に載荷し

表一1 供試版の程類と埔装の支持力

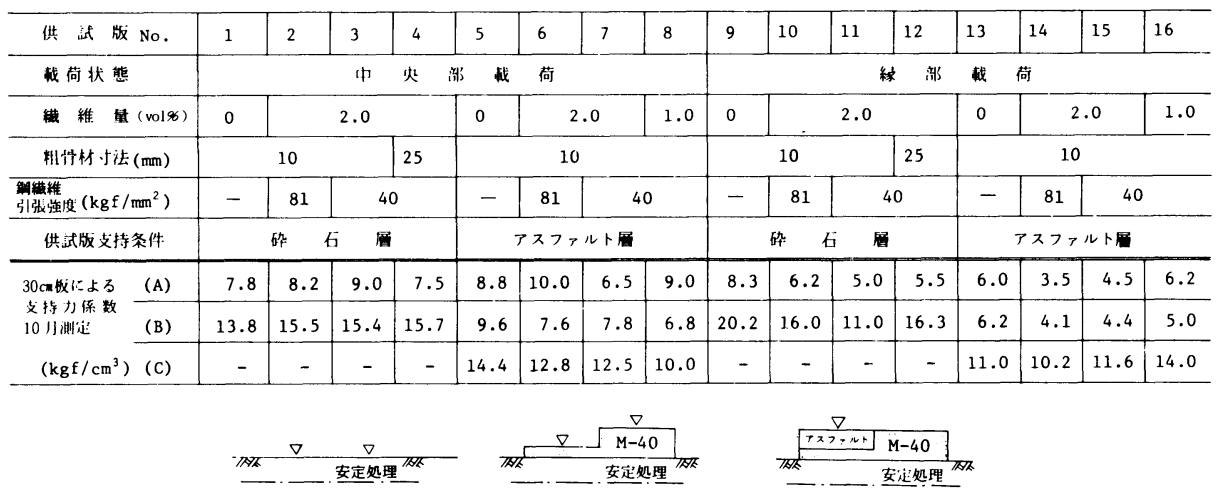


表一2 鋼緎維補強コンクリートの強度と弾性係数, ポアソン比

\begin{tabular}{|c|c|c|c|c|c|c|c|c|}
\hline \multirow{2}{*}{ 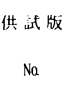 } & \multicolumn{2}{|c|}{ 標集盖 生 } & \multicolumn{2}{|r|}{ 現 } & 是巻 & \multicolumn{2}{|l|}{ 牛: } & \multirow[b]{2}{*}{$\begin{array}{l}\text { 材 分 } \\
\text { (II) }\end{array}$} \\
\hline & $\begin{array}{c}\text { 曲げ强度斗均 } \\
\left(\mathrm{kgf} / \mathrm{cm}^{2}\right)\end{array}$ & $\begin{array}{r}\text { t. 維强度平场 } \\
\left(\mathrm{kgf} / \mathrm{cm}^{2}\right)\end{array}$ & $\left(\mathrm{kgf} / \mathrm{cm}^{2}\right)$ & & 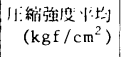 & 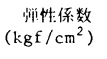 & ホアンン比 & \\
\hline 1 & 66.9 & 554 & $49.0 \sim 63.5$ & 54.5 & 661 & $33.0^{\circ} 10^{4}$ & 0.21 & 52 \\
\hline 2 & 105.8 & 598 & $107.1 \simeq 143.9$ & 125.2 & 658 & 32.3 & 0.21 & 62 \\
\hline 3 & 90.1 & 529 & $79.7 \sim 98.6$ & 90.1 & 591 & 31.9 & 0.22 & 67 \\
\hline 4 & 83.1 & 517 & $63.2 \sim 101.1$ & 82.6 & 544 & 29.5 & 0.21 & 74 \\
\hline 5 & 71.3 & 403 & $49.1 \sim 56.0$ & 51.6 & 395 & 28.6 & 0.20 & 35 \\
\hline 6 & 111.5 & 685 & $78.8 \sim 114.1$ & 96.7 & 652 & 33.9 & 0.20 & 41 \\
\hline 7 & 95.0 & 633 & $74.8 \sim 94.6$ & 86.7 & 596 & 29.7 & 0.20 & 47 \\
\hline 8 & 73.3 & 639 & $63.9 \sim 71.8$ & 66.5 & 640 & 34.1 & 0.21 & 55 \\
\hline 9 & 69.6 & 577 & $63.9 \sim 86.2$ & 79.1 & 653 & 35.3 & 0.21 & 240 \\
\hline 10 & 112.9 & 619 & $90.8 \sim 124.3$ & 107.5 & 701 & 35.4 & 0.21 & 311 \\
\hline 11 & 94.4 & 597 & $69.3 \sim 123.4$ & 100.2 & 717 & 32.8 & 0.20 & 322 \\
\hline 12 & 83.1 & 566 & $78.3 \sim 116.0$ & 96.0 & $6 \overline{56}$ & 34.7 & 0.21 & 336 \\
\hline 13 & 67.8 & 588 & $68.2 \sim 75.0$ & 71.4 & 666 & 33.6 & 0.19 & 253 \\
\hline 14 & 109.6 & 625 & $96.5 \sim 116.6$ & 105.2 & 688 & 32.3 & 0.20 & 308 \\
\hline 15 & 91.6 & 595 & $86.9 \sim 108.3$ & 95.7 & 676 & 32.3 & 0.20 & 316 \\
\hline 16 & 78.6 & 583 & $71.6 \sim 82.7$ & 79.7 & 625 & 33.2 & 0.20 & 330 \\
\hline \multicolumn{9}{|c|}{ 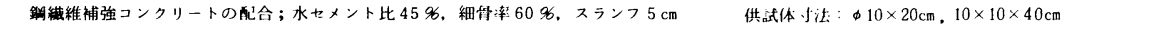 } \\
\hline
\end{tabular}

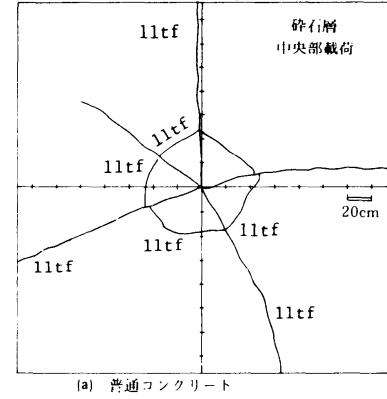

(a) 类通コンクリート

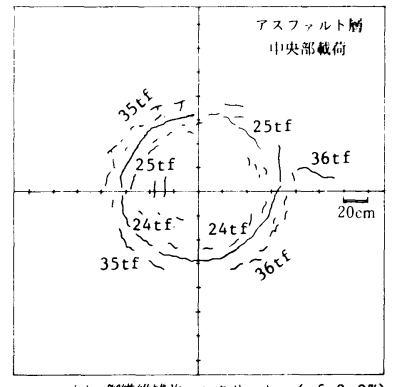

図一2 供試版のひびわれ
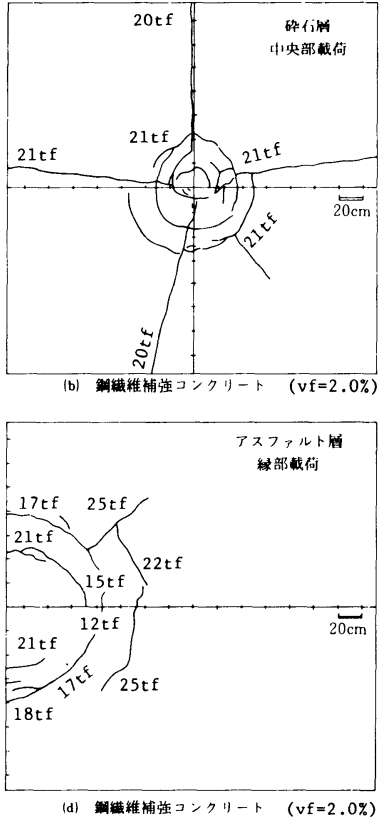

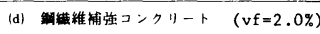

2）供試版表面に生ずるひびわれはアスファ ルト層上供試版の方が多く，また広い範囲にわ たって分布するが, その幅はきわめて小さいも のとなる．その中でほぼ円を形成すると認めら れる細いひびわれが存在する.

3）供武版表面の円形状ひびわれ発生位置 は,アスファルト層上供試版の場合に載荷中心 からの距離が大きくなる.

などが明らかとなった（図一2 (c)).

次に，供試版縁部に載荷した場合，ひびわれ は載荷縁と直角な方向のある位置にまず最初に 発生し, 荷重の増大に従って載荷縁に向かって 成長を続ける. また，放射状のひびわれが発生 して供試版は崩壊する，縁部載荷における供試 版の種類および支持層の違いによるひびわれ状 況の相違点は, 中央部載荷の場合とほぼ同様で ある(図一2（d)).

以上に示した供試版のひびわれ状況は，図一 3 に一一例を示したひずみの測定結果からも同様 に説明できる。

b）供試版のたわみ

た場合のひびわれ発生状況は, 普通コンクリートおよび 鋼繊維補強コンクリートとも砕石層上供試版の場合之ほ ぼ同様であるが, 2,3 の相違点を指摘することができる.

1）アスファルト層上の普通コンクリート供試版では 砕石層上供試版の場合と同様に放射状ひびわれが生じて 崩壊する.しかし, 供試版の鋼織維量が多くなると, 放 射状のひびわれは発生せず, 曲げによる供試版表面の微 小ひびわれと荷重付近の円形ひびわれによって供試版は 破壊する.
供試版のたわみは，ダイヤルゲージを配置したたわみ 計を用いて直接的に測定した. その測定結果の一例は図 一 4 に示すようであり, 載荷重とたわみの関係は両対数 でほぼ直線である。この関係は, また, 半無限地盤にお ける平板載荷試験から得られる式（1）と同等とみなす ことができ, 地盤状態を表わす直線の勾配と単位沈下量 当たりの荷重の大きさを求めると表一 3 のようになる.

$\log P=\log \frac{2 \cdot E \cdot a}{1-\mu^{2}}+\log w$ 
表一3 荷重-たわみ直線の勾配と単位沈下目当たりの荷重

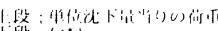

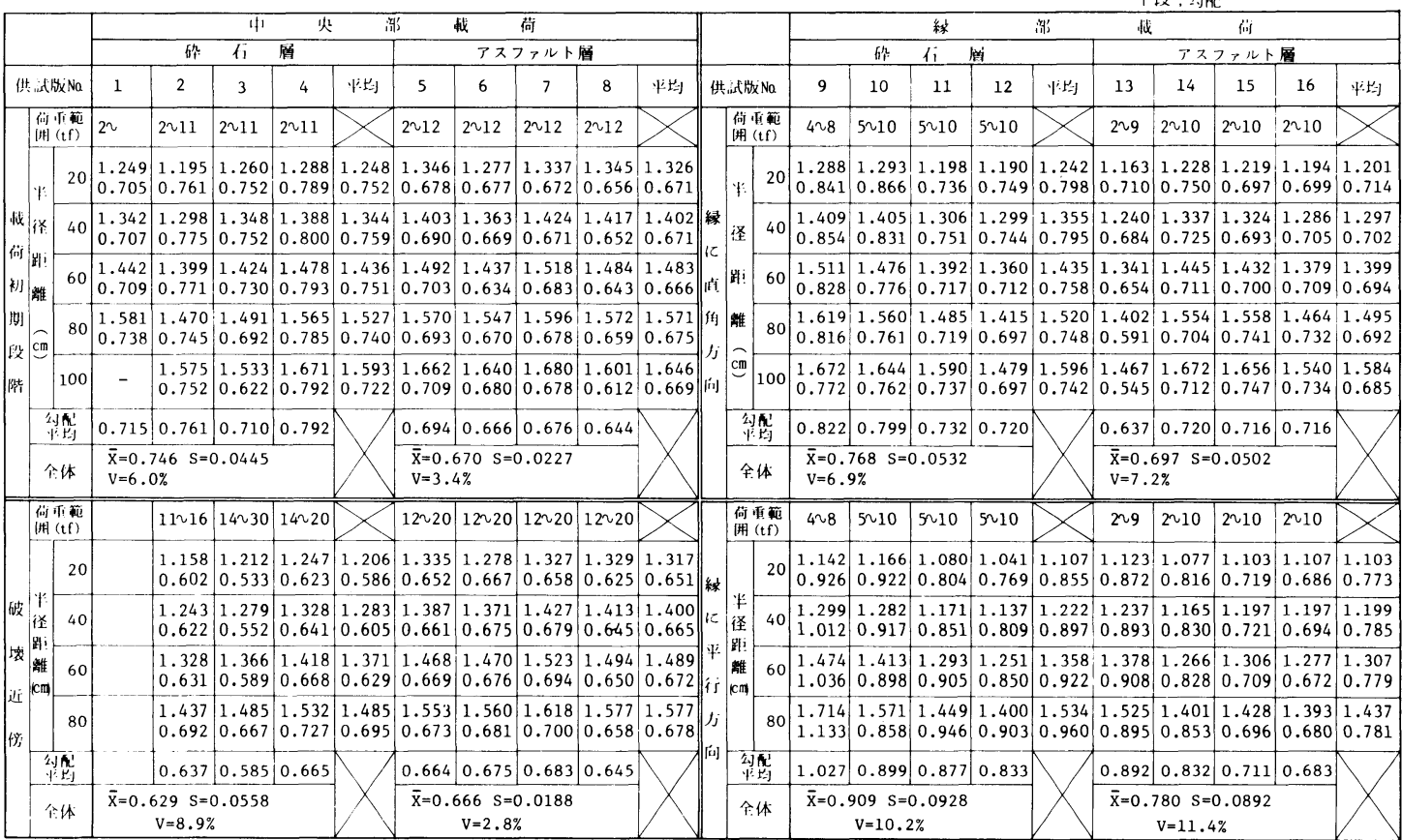
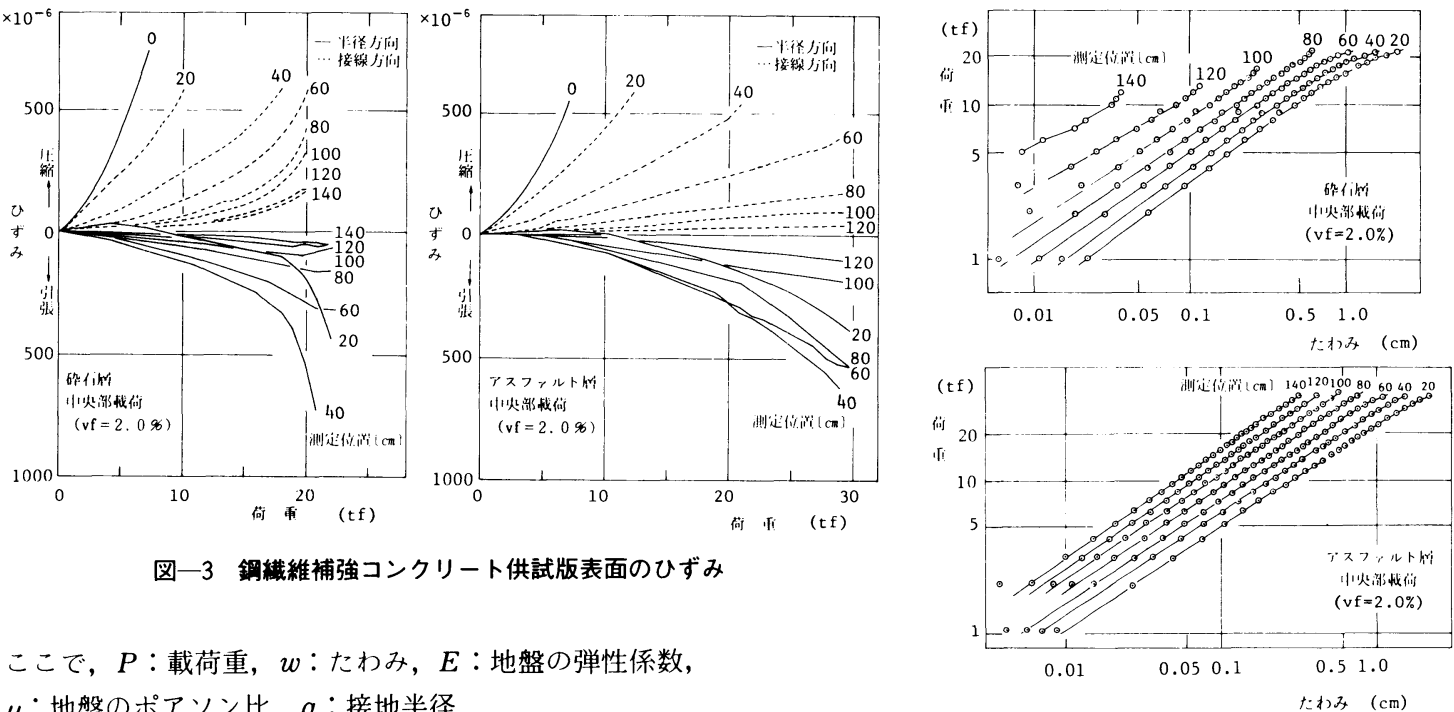

$\mu:$ 地盤のポアソン比, $a:$ 接地半径

表-3の値を比較してオーバーレイシステムを考察す

図一4鋼樍維補強コンクリート供試版のたわみ

ると, 中央部載荷の場合, 砕石層上供試版の荷重一たわ み直線の勾配は載荷初期段階と破壊荷重付近では明らか に違っており，地盤状態に何らかの変化が起こったこと が容易に推察される。しかし，アスファルト層上供試版 の場合, 直線の勾配は荷重増加によってほとんよ゙変化せ ず，地盤状態に大きな変化は生じなかったものと考えら れる. 次に, 夏期に実験した縁部載荷の場合, 中央部載 荷の場合とほぼ同じ状態にあると考えられる載荷縁に直

角な方向の各位置の荷重-たわみ直線の勾配は, 砕石層 上およびアスファルト層上供試版とも冬期に実験した中 央部載荷の同じ荷重段階での勾配にほぼ一致する。これ は, アスファルト層でも砕石層の場合と同様に，夏期と 冬期で地盤状態に大きな変化がなかったものと考えるこ とができる.しかし，単位沈下量当たりの荷重の大きさ をみると, 砕石層上供試版では中央部載荷と縁部載荷の 

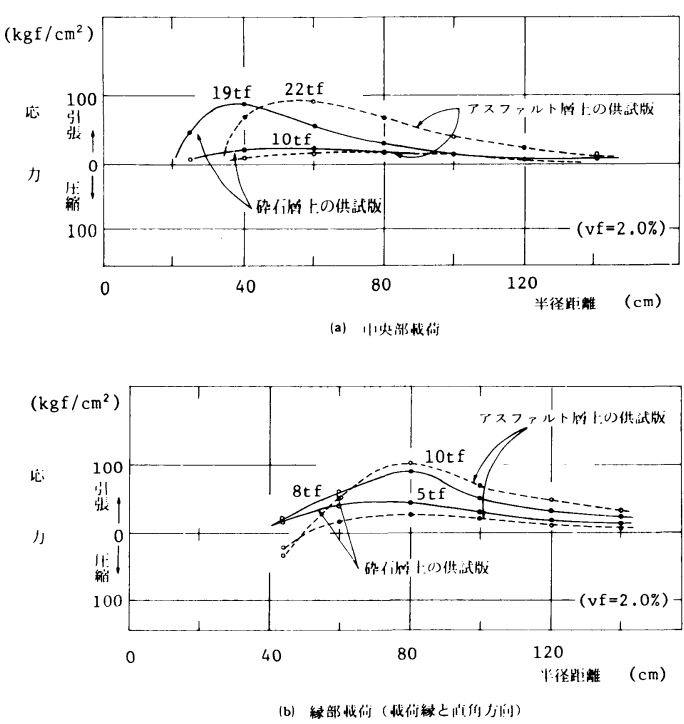

図一5鋼織維補強コンクリート供試版の半径方向の忍力

縁と直角な方向の場合に差はほとんど認められないが, アスファルト層上供試版では夏期に実施した縁部載荷の 場合に単位沈下量当たりの荷重の大きさが低下してお り,アスファルト層のスチフネスの低下がうかがわれる.

したがって，既設のアスファルト舗装を支持層とする オーバーレイシステムでは, 載荷重の大小や季節によっ てその設計手法を変える必要はなく，季節などの違いに よってアスファルト層のスチフネスの大小を考慮すれば よいものと考えられる.

c）供試版の応力分布

ひずみから計算した砕石層上およびアスファルト層上 供試版の応力分布の例は, 図一 5 に示すようである.こ れらの結果によると, 砕石層上とアスファルト層上供試 版の応力状態には明らかな違いがあり, アスファルト層 上供試版の場合には最大応力の生ずる位置が砕石層上の 場合よりも大きく, また最大応力付近の応力分布の形状 も緩やかなものとなっているのがわかる.

弾性床上平板の剛比半径は式 ( 2 ) によって求まる ${ }^{10)}$.

$$
l=\sqrt[4]{\frac{E \cdot h^{3}}{12\left(1-\mu^{2}\right) K}}
$$

ここで, $l:$ 剛比半径, $E:$ 平板の 弾性係数, $\mu$ : 平板のポアンン比, $h:$ 平板の厚さ, $K:$ 地盤 (弾性床) の支持力係数

一般に, 弾性床上の平板では, 剛 比半径の大きいものほど最大モ一メ ントの生ずる位置が中心より離れ, またモーメント分布も緩やかな形状 となる ${ }^{101}$. 本実験の場合, 供試版の
厚さと鋼瀻維補強コンクリートの品質は砕石層上および アスファルト層上供試版とも同一であるので, アスファ ルト層上供試版における最大応力の発生位置の変化と応 力分布形状の変化は主にアスファルト層に原因があると 考えられる.すなわち, 鋼繊維補強コンクリートオーバー レイシステムにおけるアスファルト層はコンクリート版 と一体となって挙動し，両者が複合して機能することに より剛比半径を大きくしたものと考えることができる。

\section{3. 一般道路における載荷実験}

\section{(1) 実験 概 要}

オーバーレイシステムにおけるアスファルト層の機能 についての考え方はすでに2．で述べたとおりであり， 本研究ではコンクリート平板とアスファルト層が一体と なって挙動する複合版の概念を適用することにした．本 章で述べる載荷実験は，その場合に必要となるアスファ ルト層のスチフネスを求めるために実施したもので,一 般道路において実施した大型ダンプトラックによる走行 載荷および静止載荷実験を主な内容としている.

試験舗装の断面構成は図一6に示すとおりで, アス ファルト舗装を $15 \mathrm{~cm}$ 切削し, 版長 $50 \mathrm{~m}$, 幅員 $3.35 \mathrm{~m}$ の鋼繊維補強コンクリートオーバーレイを実施したもの である．使用した鋼瀻維補強コンクリートは，普通ポル トランドセメントを用いた表一 4 の配合のもので，レ デーミクストコンクリート工場で製造し，ダンプトラッ クで現場に運搬し，簡易フィニッシャーで締め固めた後 ただちに真空養生を実施した。鋼瀻維補強コンクリート の曲げ強度, 弾性係数およびポアソン比の測定結果は併 せて表一 4 に示すとおりである.

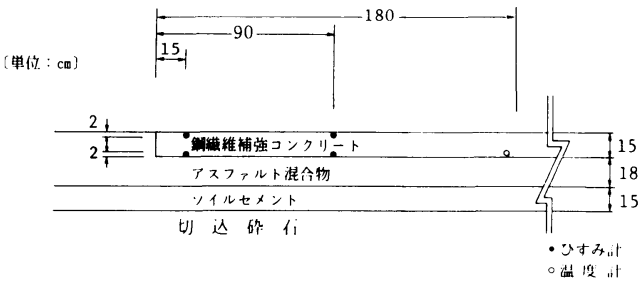

図一6 試験垡装の断面構成

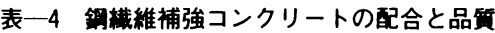

\begin{tabular}{|c|c|c|c|c|c|c|c|c|c|c|}
\hline \multirow{2}{*}{$\begin{array}{c}\text { 粗背材 } \\
\text { 最大寸抾 } \\
\text { (mm) }\end{array}$} & \multirow{2}{*}{$\begin{array}{c}\text { スランフ } \\
\text { (cm) }\end{array}$} & \multirow{2}{*}{ 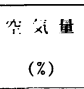 } & \multirow{2}{*}{$\begin{array}{l}\text { 水・セx } \\
\text { vitt } \\
\text { w/c } \\
(\%)\end{array}$} & \multirow{2}{*}{$\begin{array}{c}\text { 絒线材染 } \\
\text { s/a } \\
(\%) \\
\end{array}$} & \multicolumn{2}{|c|}{ 巣 位 喠 } & \multicolumn{2}{|c|}{$\left(\mathrm{kgf} / \mathrm{m}^{3}\right)$} & \multirow[b]{2}{*}{ G } & \multirow[b]{2}{*}{ 㳐和 剂 } \\
\hline & & & & & SF & w & C & $\mathrm{s}$ & & \\
\hline 25 & $5 \pm 1$ & $4 \pm 1$ & 45 & 60 & 120 & 202 & 449 & 936 & 636 & 1.12 \\
\hline
\end{tabular}

\begin{tabular}{|c|c|c|c|c|c|}
\hline 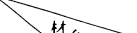 & & 䏍度 & $\left(\mathrm{kgf} / \mathrm{cm}^{2}\right)$ & \multirow{2}{*}{$\begin{array}{c}\text { 弹 性 係 数 } \\
\left(\mathrm{Kgf} / \mathrm{cm}^{2}\right)\end{array}$} & \multirow{2}{*}{ ホアリン比 } \\
\hline 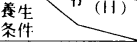 & 3 & 4 & 7 & & \\
\hline 標 隼 特: & 57.1 & 65.0 & 78.1 & \multirow{2}{*}{$32.2 \times 10^{4}$} & \multirow{2}{*}{0.23} \\
\hline 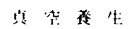 & 58.7 & 67.4 & 70.8 & & \\
\hline
\end{tabular}


載荷の方法は, 輪荷重を 5 トンおよび 3 トンに調整し たダンプトラックを用い, 走行載荷の場合には速度約 $10 \mathrm{~km} / \mathrm{h}$ で埋設したひずみ計の直上を走行させ, 静止載 荷の場合にはダンプトラックをひずみ計の直上で静止さ せた。ひずみ計および温度計は, 鋼織維補強コンクリー トオーバーレイを走行する荷重の載荷時間, 発生ひずみ, 舗装の温度などを調べる目的で, 版端から $25 \mathrm{~m}$ の図一 6 に示す位置に埋設した。

\section{（2）コンクリート平板とアスファルト属の複合版}

本研究で適用した複合版の概念は図一7に示すようで あり、コンクリート版部分に生ずる応力分布と同じ応力 分布が得られるように，2層の厚さを 1 層のみよりなる 場合の厚さに等值換算するものである ${ }^{11}$. この場合, 上 下層境界面での滑りの存在が複合性を考えるうえで重要 となるが，2．で述べた載荷実験によればコンクリート 版とアスファルト層の付着はきわめて良好であり, 境界 面での滑りは特にないように思われた.

式 (3) は, 複合版厚を求める式である.

$$
\begin{gathered}
H_{1}^{*}=\frac{1+2 \cdot \alpha \cdot \beta+\alpha \cdot \beta^{2}}{1+\alpha \beta} H_{1} \cdot \\
\alpha=\frac{E_{2}\left(1-\mu_{1}^{2}\right)}{E_{1}\left(1-\mu_{2}^{2}\right)}, \beta=\frac{H_{2}}{H_{1}}
\end{gathered}
$$

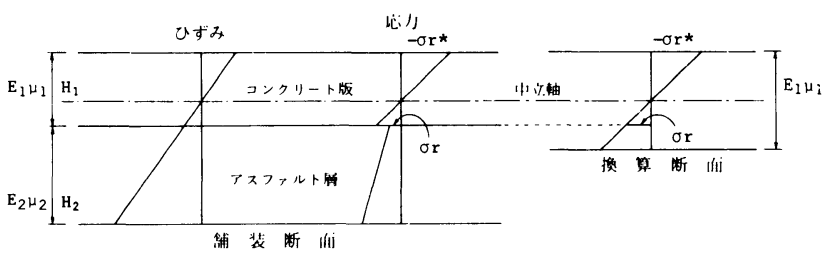

図一7 複合版の概念
ここで, $H_{1}^{*}$ : 複合版厚, $E_{1}, E_{2}$ : コンクリート版とア スファルト層の弾性係数あるいはスチフネス, $\mu_{1}, \mu_{2}$ : コンクリート版とアスファルト層のポアンン比, $H_{1}$, $H_{2}$ : コンクリート版とアスファルト層の厚さ

\section{（3） アスファルト舗装のスチフネス}

アスファルト混合物のスチフネスは, 一般に温度, 載 荷時間, 使用アスファルトの性質および混合物の配合に よって影響を受ける ${ }^{22}$. したがって，本載荷実験では鋼 繊維補強コンクリート版に埋設された上下のひずみ計の 測定值から実際の効果としてのアスファルト層のスチフ ネスを求めることにし, 次に載荷時間を求めることので きる走行載荷実験の場合についてはVan der Poel らの 方法 ${ }^{31}$ に従って求めた計算結果も比較することにした。

上下ひずみの差から求めた複合版厚とアスファルト層 のスチフネスは表一5に示すようである.アスファルト 層は, 走行載荷の場合約 $2 \sim 5 \mathrm{~cm}$ 程度, 静止載荷の場 合約 $0.3 \sim 2 \mathrm{~cm}$ 程度鋼織維補強コンクリートの版厚を 増したのと同様な効果を示した。また,これと対応した アスファルト層のスチフネスは, 走行載荷の場合, 冬期 で約 $45000 \mathrm{kgf} / \mathrm{cm}^{2}$, 夏期で約 $20000 \mathrm{kgf} / \mathrm{cm}^{2}$ 程度とな り, 静止載荷の場合では冬期に約 $8000 \mathrm{kgf} / \mathrm{cm}^{2}$, 夏期 に約 $1000 \mathrm{kgf} / \mathrm{cm}^{2}$ 程度となった。アスファルト混合物 のスチフネスは多くの研究者達が種々の方法 によって求めている(21,131 が, オーバーレイシ ステムにおける実際的な効果としてのスチフ ネスがここで得られたものと考える. また， この値を用いて求めた一連の供試版載荷実験 の結果は，5．の基本設計式の検討でも用い られている.

次に，載荷速度を求めることのできる走行

\begin{tabular}{|c|c|c|c|c|c|c|c|}
\hline & \multirow{2}{*}{$\begin{array}{l}\text { 実 } \\
\text { 施 } \\
\text { 月 }\end{array}$} & \multirow{2}{*}{$\begin{array}{c}\text { 荷 } \\
\text { 雨 } \\
(\mathrm{tf})\end{array}$} & \multicolumn{2}{|c|}{ ひすみ指亦俌 } & \multicolumn{2}{|c|}{$\begin{array}{r}\text { 裸合版 }(1,5 \\
(\mathrm{cm})\end{array}$} & \multirow{2}{*}{ 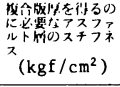 } \\
\hline & & & 中赴上側芐侧 & 絊 上例 下湖 & 中尖 & 称 & \\
\hline \multirow{4}{*}{$\begin{array}{l}\text { 走 } \\
\text { 行 } \\
\text { 荷 } \\
\text { 南 } \\
\text { 战 } \\
\text { 荷 }\end{array}$} & \multirow{2}{*}{$3 H$} & 3 & & & 18.0 & 17.1 & \multirow{2}{*}{$\begin{array}{l}15000 \\
\sim \\
25000\end{array}$} \\
\hline & & \multirow{3}{*}{5} & & & 17.2 & 16.9 & \\
\hline & $8 H$ & & & & 17.1 & 17.6 & $\begin{array}{l}17000 \\
\sim 21000\end{array}$ \\
\hline & 1月 & & & & 20.9 & 19.0 & $\begin{array}{l}35000 \\
\sim 54000\end{array}$ \\
\hline \multirow{4}{*}{$\begin{array}{l}\text { 觧 } \\
\text { 此, } \\
\text { 荷 } \\
\text { 重 } \\
\text { 載 } \\
\text { 倚 }\end{array}$} & & 3 & & & 16.7 & - & \multirow{2}{*}{$\begin{array}{l}5000 \\
\sim \\
13000\end{array}$} \\
\hline & & \multirow{3}{*}{5} & & & 16.8 & 15.6 & \\
\hline & 8 H & & & & 15.3 & 15.3 & $\begin{array}{l}1000 \\
\sim \\
2000\end{array}$ \\
\hline & $11]$ & & 29 & & 16.2 & 15.8 & $\begin{array}{l}6000 \\
\sim \\
\quad 9000\end{array}$ \\
\hline
\end{tabular}

表一5 走行荷重および睁止荷重线荷実硂結果

\begin{tabular}{|c|c|c|c|c|}
\hline \multicolumn{4}{|c|}{ アスファルト猵 } & \multirow{2}{*}{$\begin{array}{c}\text { (10)式による } \\
\text { 挴合版惊 } \\
\text { (cm) }\end{array}$} \\
\hline 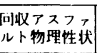 & ${ }^{8}{ }^{\circ}$ 度) & 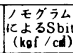 & 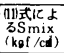 & \\
\hline${ }_{37}$ & 8.4 & 500 & 26000 & 18.2 \\
\hline \multicolumn{5}{|l|}{ 软化点 } \\
\hline \multirow[t]{2}{*}{$\begin{array}{l}\text { PI } \\
-0.49\end{array}$} & 32.7 & 10 & 1300 & 15.2 \\
\hline & 4.9 & 1200 & 47000 & 20.3 \\
\hline
\end{tabular}

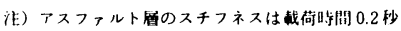
节材体皘垶 $\mathrm{Cv}=0.80$ として求めた 
載荷実験の場合, アスファルト層は鋼綫維補強コンク リート版の下面で測定した温度変化とひずみ変化を有し ていると考えた。アスファルトの性状は現場切取供試体 からアスファルトを回収して調べ, Van der Poel らの ノモグラムを用いてアスファルトのスチフネスを求め た。またアアスファルト混合物のスチフネスは式（4) から求めた。

$$
\begin{aligned}
S_{\mathrm{mix}} & =S_{\text {bit }}\left(1+\frac{2.5}{n} \frac{C_{v}}{1-C_{v}}\right)^{n} \\
n & =0.83 \log \left(4 \times 10^{5} / S_{\text {bit }}\right)
\end{aligned}
$$

ここで, $S_{\mathrm{mix}}$ ：アスファルト混合物のスチフネス, $S_{\mathrm{bit}}$ : アスファルトのスチフネス, $C_{v}$ : 骨材体積率

このようにして求めたアスファルト層のスチフネスお よび複合版厚は併せて表一 5 に示している，前述の結果 と比較すると, 夏期の場合に差が生じているものの, 冬 期および春期の場合はよく一致している. まだ多くの場 合について検討する必要はあるが, 車両の走行する実際 のオーバーレイではV an der Poel らの方法によってア スファルト層のスチフネスを求めるのも有効な手段であ るように思われる.

\section{4. 鋼織維補強コンクリートオーバーレイ厚の 設計式}

舗装が損傷を受けて崩壊してゆく場合, どの時点を破 壊として定義するかはきわめて難解な問題である.これ は，走行する交通に対して快適な走行性が満足されるな ら舗装は良好な状態にあるとする立場とコンクリート版 にひびわれが生じたなら舗装は破壊したとする立場が必 ずしも同時に成立しないからである．2．に述べた供試 版における載荷実験の結果をもとに鋼織維補強コンク リートオーバーレイシステムの破壊をみると, 結果はい ずれも鋼綫維補強コンクリートがひびわれ発生に対して 非常に大きな抵抗性をもち，ひびわれ発生後も優れたひ びわれ抑制能力と大きな耐荷力を有していることを示し ている．また，既設のアスファルト舗装を支持層とする オーバーレイの場合には,そのアスファルト層も耐久的 な荷重支持層として期待できることを示している，した がって, 本研究では優れた鋼瀻維補強コンクリートの特 性を利用することを考え, オーバーレイシステムの破壊 を次のように定めた.すなわち，弾性床上平板に生ずる 一般的な曲げモーメントの図一 8 を参考にして, 負の モーメントによってオーバーレイ表面にひびわれが生ず る時点を破壊とした. 正のモーメントによって生ずるひ びわれは, 鋼織維によって連続が保たれ，せん断力の伝 達と版の平滑な連続性が確保できると考えられ, また舖 装本来の目的であるサービス性からもこのひびわれは許 容できるものと考えた。

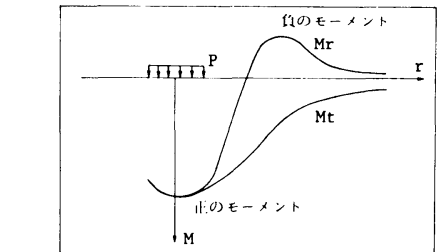

図一8 コンクリート版に生ずるモーメント

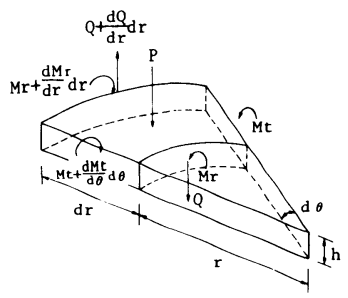

図一9＼cjkstart微小要秦のつり合い

本研究では, 1960 年代に Meyerhofによって提案さ れた降伏線法 ${ }^{14)}$ (yield-line theory) をもとに，上述の ような破壊に対する基本設計式を考えた。この降伏線法 の概要は以下のとおりである.

載荷中心から距離 $r$ にある微小要素に作用する力の 状態を考えると図一9のようである，要素に働く垂直力 およびモーメントのつり合いを考え，さらに高次の微小 量を無視すると, 次の 2 つのつり合い方程式が得られる.

（垂直力）

$$
\begin{aligned}
& p \cdot r+Q+r \frac{d Q}{d r}=0 \quad \therefore \frac{d(r Q)}{d r}=-r \cdot p \cdots \cdots \cdots( \\
& (\text { モーメント) } \\
& r \cdot Q+M_{t}-r \frac{d M_{r}}{d r}-M_{r}=0 \\
& \therefore \frac{d\left(r \cdot M_{r}\right)}{d r}=M_{t}+r \cdot Q \cdots \cdots \cdots \cdots \cdots \cdots \cdots(
\end{aligned}
$$

ここで, $p$ : 荷重強度, $Q$ : 単位長当たりのせん断力, $M_{r}$, $M_{t}$ : 半径方向および接線方向の単位長当たりのモーメ ント

さらに，設計式を簡略化するために，版はWinkler 基礎に支えられており，たわみ形状も線形であると仮定 すると式 ( 7$) ，(8)$ が得られる.

$$
\begin{aligned}
& p=-k \cdot w \cdots \cdots \\
& w=(1-r / t) w_{0}
\end{aligned}
$$

ここで， $k$ : 地盤係数， $w$ : 版のたわみ， $t$ ：たわみを 線形とした場合の円錐の半径， $w_{0}$ ：載荷中心のたわみ

また，破壊は版に生ずる負のモーメントによってひび われが生ずる状態であり， $r=b$ で $M_{r}=-M_{0}$ および $M_{t}=M_{0}\left(M_{0}\right.$ : 版の抵抗モーメント) が破壊条件となる. したがって,ランキンの降伏条件を用い, 式 (5)，（７), 
（８）から降伏条件の範囲内で式( 6 ) を積分して半径方向の曲げモーメン ト， $M_{r}$ を求めると式（9) のよう になる。

$$
\begin{aligned}
M_{r} & =M_{0}+\frac{k w_{0} r^{2}}{6}\left(1-\frac{r}{2 t}\right) \\
& -\frac{k w_{0} t^{2}}{6}\left(1+\frac{2}{3} \frac{c}{r}\right) \cdots(9)
\end{aligned}
$$

また, Losbergによれば ${ }^{15)}$, ひび われは $r=b$ の位置に生ずることから， $r=b$ で $M_{r}$ は 最大とならなければならず，式（9）を整理しなおすと 次のように破壊たわみを求める式が得られる.

$$
w_{0}=\frac{12 M_{0}}{k b^{2}\left\{3\left(\frac{b}{c}-1\right)-\frac{2 b}{t}\left(\frac{9 b}{8 c}-1\right)\right\}}
$$

破壊荷重は式（10）に式（7）および（8）を代入す ることにより次のように与えられる。

$$
P=k \cdot \pi \cdot t^{2} \cdot w_{0} / 3 \cdot
$$

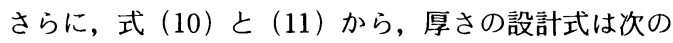
ようになる。

$$
H_{1}^{*}=\left[\frac{3 \cdot P \cdot b^{2}}{2 f_{b} \pi \cdot t^{2}}\left\{3\left(\frac{b}{c}-1\right)-\frac{2 b}{t}\left(\frac{9 b}{8 c}-1\right)\right\}\right]^{1 / 2}
$$

\section{ここで， $f_{b}$ : 鋼緎維補強コンクリートの曲げ強度}

\section{5. 基本設計式の検討}

鋼緎維補強コンクリートオーバーレイに関する基本設 計式として式 (10)，(11）および（12）を得たが, 実際 の運用にあたっては式の妥当性が確認されていなければ ならない，本章では，2．に示した一連の載荷実験の結 果をもとに式の適用性を検討する。

基本設計式にはまだ定まっていない定数値 $k, b, c$ および $t$ があり，これらの定数値はオーバーレイを設 計する際に必要である．設計式の実用性からこれらの定 数值は簡単な現場試験などから測定されるものでなけれ ばならない，本研究では，鋼繊維補強コンクリート版あ るいはアスファルト層との複合版の剛比半径と対比させ て求める方法を提案する. 定数値 $b, c$ および $t$ は版の たわみ形状に強く影響を受けるので, 剛比半径と関連し て求めることには十分合理性があると思われる.

\section{（1） 定数值の決定}

a) 数 值 $k$

$k$ は地盤係数で，表一 1 (b) 断面における平板載荷 試験から求めることができると考えていたが，供試版に 関する一連の載荷実験の結果は版の相当大きなたわみを 示した．したがって， $0.125 \mathrm{~cm}$ 程度の沈下から求める 通常の地盤支持力係数は数值 $k$ として適当でなく，版

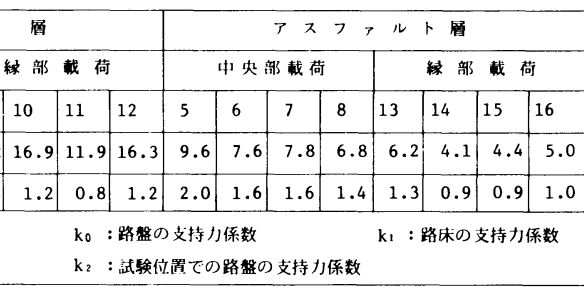

のたわみが大きい場合では路床の影響がかなり大きくな ること, 地盤の変形と地盤支持力係数および外力の間に は式（ 7 ）のようなつり合いがあることなどを考虑して, 数値 $k$ は路床の平板載荷試験の結果から平均的に 1.1 $\mathrm{kgf} / \mathrm{cm}^{3}$ とした．また，数值 $k$ は場所ごとの変動を反映 しなければならず，平板載荷試験の結果を表一6に示す ように補正して検討に用いた。

b) 数値 $b, c$ および $t$

数值 $b$ は版に生ずる負の曲げモーメントが最大とな る点であって, 版表面の半径方向の応力分布図と円形ひ びわれの発生位置から求めることができる. また，数值 $c$ は破壊たわみ式（10）を求める際の境界点で, $0<c<b<t$ で規定される点である. 今回の場合，連続 な点として半径方向モーメントが 0 となる点を選び，応 力分布図で応力が 0 となる点を採用した。このような点 を選定すれば, 版の剛比半径との関係も明確となり, 数 值 $b$ との関係からも好都合であると思われた．数值 $t$

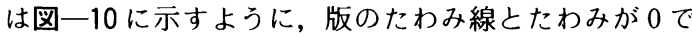
ある線との交点である。この数值 $t$ は，実際には表一 3 に示す荷重一たわみ直線の勾配および単位沈下量当た りの荷重から $b$ 点および $c$ 点のたわみを推定して求め るもので, 荷重が増加すると変化する， しかし，各荷重 段階でこの值を求めてみるとしだいに一定値に漸近し, 特に破壊に近い状態では荷重を増加してもほとんど変化 しないことが明らかとなった。

このようにして求めた定数値と剛比半径との比は表一 7 に示すようである. 数值 $b, c, t$ の剛比半径に対す る割合は, 支持層之載荷条件が決まればほぼ一定となり， 基本設計式を十分簡略できるものと思われる.

\section{（2）破壊たわみおよび破壊荷重の計算値と実測値}

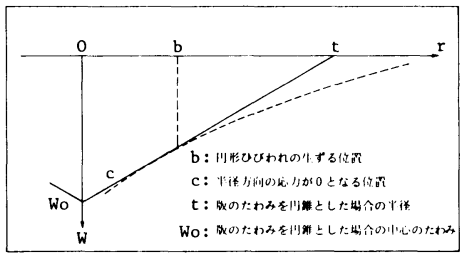

図一10供試版のたわみ变形 
表一 7 係数 $b, c, t$ の值

\begin{tabular}{|c|c|c|c|c|c|c|c|c|c|c|c|c|c|c|c|c|c|}
\hline \multirow{3}{*}{\multicolumn{2}{|c|}{ 供鶮版 }} & \multicolumn{4}{|c|}{ 研 } & \multicolumn{4}{|c|}{ 植 } & \multicolumn{8}{|c|}{ アスフフルト简 } \\
\hline & & \multicolumn{4}{|c|}{ 中央部载荷 } & \multicolumn{4}{|c|}{ 䋨部载荷 } & \multicolumn{4}{|c|}{ 中央部載荷 } & \multicolumn{4}{|c|}{ 䋨部载荷 } \\
\hline & & 1 & 2 & 3 & 4 & 9 & 10 & 11 & 12 & 5 & 6 & 7 & 8 & 13 & 14 & 15 & 16 \\
\hline \multicolumn{2}{|c|}{ 喇比半径是 } & 27.5 & 26.6 & 26.6 & 25.9 & 25.4 & 26.6 & 28.5 & 26.7 & 40.5 & 43.1 & 42.7 & 44.4 & 35.2 & 38.9 & 38.0 & 37.1 \\
\hline 係 & 数 $\mathrm{cm}$ & 41.0 & 34.0 & 36.0 & 38.0 & 70.0 & 70.0 & 78.0 & 69.0 & 65.0 & 60.0 & 60.0 & 60.0 & 76.0 & 82.0 & 80.0 & 80.0 \\
\hline & $\mathrm{b} / \mathrm{l}$ & 1.5 & 1.3 & 1.4 & 1.5 & 2.8 & 2.6 & 2.7 & 2.6 & 1.6 & 1.4 & 1.4 & 1.4 & 2.2 & 2.1 & 2.1 & 2.2 \\
\hline 平 & 均 & \multicolumn{4}{|c|}{.4} & \multicolumn{4}{|c|}{2.7} & \multicolumn{4}{|c|}{1.4} & \multicolumn{4}{|c|}{2.2} \\
\hline 係 & 数 $\mathrm{c}$ & 25 & 20 & 20 & 20 & 36 & 40 & 40 & 42 & 35 & 32 & 32 & 32 & 42 & 50 & 49 & 45 \\
\hline & $c / \ell$ & 0.9 & 0.75 & 0.75 & 0.75 & 4 & 1.5 & 1.4 & 1.6 & .86 & 0.74 & 0.75 & 0.72 & 1.2 & 1.3 & 1.3 & 1.2 \\
\hline 平 & 均 & \multicolumn{4}{|c|}{0.75} & \multicolumn{4}{|c|}{1.5} & \multicolumn{4}{|c|}{0.75} & \multicolumn{4}{|c|}{1.3} \\
\hline 係 & $\begin{array}{l}\text { 数 } \mathrm{t} \\
\mathrm{km} \\
\mathrm{km}\end{array}$ & 83.6 & 89.2 & 95.1 & 88.4 & 127.7 & 144.7 & 127.4 & 146.6 & 112.7 & 111.5 & 109.9 & 116.1 & 121.2 & 128.8 & 124.3 & 135.9 \\
\hline & $t / \ell$ & 3.0 & 3.4 & 3.6 & 3.4 & 5.0 & 5.4 & 4.5 & 5.5 & 2.8 & 2.6 & 2.6 & 2.6 & 3.4 & 3.3 & 3.3 & 3.7 \\
\hline 平 & 均 & \multicolumn{4}{|c|}{.4} & \multicolumn{4}{|c|}{5.1} & \multicolumn{4}{|c|}{2.6} & \\
\hline
\end{tabular}

表一8＼cjkstart破壊たわみおよび破壊荷重の実測値と計算值

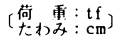

\begin{tabular}{|c|c|c|c|c|c|c|c|c|c|c|c|c|c|c|c|c|}
\hline & \multicolumn{8}{|c|}{ 石 } & \multicolumn{8}{|c|}{ 了スファルト砶 } \\
\hline & \multicolumn{4}{|c|}{ 中央部載荷 } & \multicolumn{4}{|c|}{ 縔部载荷 } & \multicolumn{4}{|c|}{ 中央部载荷 } & \multicolumn{4}{|c|}{ 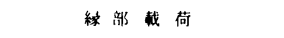 } \\
\hline & 1 & 2 & 3 & 4 & 9 & 10 & 11 & 12 & 5 & 6 & 7 & 8 & 13 & 14 & 15 & 16 \\
\hline 䒠測 & 0.97 & 1.71 & 1.70 & 1.64 & 0.53 & 0.62 & 0.76 & 0.54 & 1.24 & 1.09 & 1.20 & 1.13 & 0.55 & 0.84 & 0.99 & 0.94 \\
\hline 彭 & 1.08 & 2.45 & 1.76 & 1.67 & 0.46 & 0.66 & 0.81 & 0.58 & 0.69 & 1.29 & 1.27 & 0.95 & 0.57 & 0.99 & 0.94 & 0.74 \\
\hline 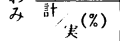 & 111.3 & 143.3 & 103.5 & 101.8 & 86.8 & 106.5 & 106.6 & 107.4 & 55.6 & 118.3 & 105.8 & 84.1 & 103.6 & 117.9 & 94.9 & 78.7 \\
\hline 実測 & 11.0 & 17.0 & 19.2 & 20.3 & 7.0 & 9.0 & 8.0 & 7.0 & 20.9 & 18.7 & 21.9 & 21.0 & 7.5 & 9.4 & 9.8 & 9.6 \\
\hline 就算 & 9.9 & 23.0 & 16.6 & 15.0 & 5.6 & 7.6 & 7.1 & 6.8 & 16.1 & 27.1 & 26.1 & 18.5 & 5.5 & 8.1 & 7.4 & 6.2 \\
\hline 容 $(\%)$ & 90.0 & 135.3 & 86.5 & 73.9 & 80.0 & 84.4 & 88.1 & 97.1 & 77.0 & 144.9 & 119.2 & 88.1 & 73.3 & 86.2 & 75.5 & 64.6 \\
\hline
\end{tabular}

4.の式（10）および（11）によって求めた供試版の 破壊たわみおよび破壊荷重は表一8に示すようであり， 破壊たわみおよび破壊荷重の実測値と比較すると，まず 破壊たわみの場合, 両者の值はかなりよく一致している のがわかる、これを計算値/実測値の適合率で示すとほ ぼ 85 115％の範囲にある. 適合率の悪い 2 例（143.3 \%，55.6\%）についてはその原因が明らかで，前者は 採取した供試体の強度, 後者は供試版のたわみ性状に主 な原因がある.

破壊荷重の場合, 計算値は総体的に実測値よりも小さ くなっており，適合率でみるとおおよそ $75 \sim 90 \%$ の範 井である. 破壊荷重を求める式（11）は線形的なたわみ 挙動を仮定しているが, 供試版の実際のたわみが対数線 形的な挙動であることなどの影響が現われているものと 思われる、したがって, 実際のたわみ挙動を計算に組み 込むことができるなら破壊荷重の計算値と実測値はさら に精度よく一致するであろう. 事実, 載荷中心の荷重たわみ線を表一 3 から推定して破壊荷重を求めると 10 $\%$ 程度適合率が向上する.

式 (10)，(11）および（12）が含む誤差についてさら に考察する.路床・路盤の支持力, 鋼繊維補強コンクリー
卜の強度, さらに測定誤差も含めた式（10）に影響を及 ぼすすべての要因が正規分布の変動を有しているものと するならば，本研究で求めた計算值/実測值で表わす適 合率もまた正規分布の変動を有しているものと考えられ る.ここで, 破壊荷重を求める式は線形的なたわみ挙動 の仮定による影響が大きいので，たわみの適合率に着目 してその変動程度を調べると, 適合率の平均は 1.019 (101.9\%) で変動係数は $11.5 \%$ となり, 式（10）は かなり精度のよい推定式であることがわかる.すなわち， 変動係数に态じた適切な安全率とオーバーレイシステム を構成する各材料の疲労をさらに考慮することにより， 式(10), (11) および(12)を用いて鋼緎維補強コンクリー トオーバーレイの設計が可能であると考えられる.

\section{6. 結} 論

供試版と一般道路における実際のオーバーレイに載荷 実験を実施し，既設アスファルト舖装を支持層とする鋼 繊維補強コンクリートオーバーレイシステムの有効性, 設計法などを検討した．本研究で得られた成果を要約す ると以下のようである.

（1）供試版における載荷実験の結果，鋼綫維補強コ 
ンクリートはひびわれ発生に対して非常に大きな抵抗性 をもち，ひびわれ発生後も優れたひびわれ抑制能力と大 きな耐荷力を有していることを示した。

（2）本研究が対象とするオーバーレイシステムにお けるアスファルト層は，鋼繊維補強コンクリート版と一 体になって荷重を支持し，鋼繊維補強コンクリート版の 厚さを増加させた場合と同等の効果を示した。したがっ て，オーバーレイシステムとしてアスファルト層のスチ フネスを適切な方法で求めることにより，アスファルト 層とコンクリート版の複合版の概念を適用して鋼緎維補 強コンクリートオーバーレイを設計することができるこ とを示した。

（3）鋼瀻維補強コンクリート供試版のひびわれ状 況，たわみ性状などの結果から，負のモーメントによっ て版表面にひびわれが発生した状態をもってオーバーレ イシステムの破壊とみなせることを示した。ささらにこの ような破壊状況に対するオーバーレイシステムの設計方 法として，降伏線法による基本式（10)，(11)，(12）が 適用できることを示した。

（4）基本設計式から求めた鋼緎維補強コンクリート 版の破壊たわみおよび破壊荷重を実測值と比較して, 設 計式の妥当性，実用性を確認した。

謝辞：本研究を進めるにあたり，終始有益なご助 言とご指導を頂いた東京大学生産技術研究所，小林一輔 教授ならびに東北大学工学部，福田正教授に深甚の謝意 を表する次第です。また，本研究の主要な部分を成す走 行載荷実験では, 建設省中部地方建設局名古屋国道工 事々務所の白村所長, 丸山工務課長をはじめとする事務 所の皆様抄よび中部技術事務所の皆様に多くのご指導を 頂きました。ここに改めて感謝の意を表する次第です。

\section{参考文 嗝}

1) 小林一輔：織維補強コンクリート一特性と応用一, オーム 社, 1981 年.
2）鋼織維補強コンクリート設計施工指針（案)，コンクリー トライブラリー50 号, 土木学会, 1983 年.

3）伊吹山四郎・國分修一・大島朋之：鋼織維補強コンク リートの曲げ疲労特性, 第 1 回コンクリート工学年次講 演会論文集, pp. 421 424, 1979 年.

4）小林一輔・井上武美：鋼織維補強コンクリートによる舗 装, コンクリート工学, Vol.14, No.6, pp. 50〜54,1976 年.

5) 奥野正和・國分修一・桜井 浩・伊藤 跤：鋼織維補強 コンクリートのオーバーレイへの適用, 道路建設, No. 354,1977 年.

6）伊吹山四郎・瀬戸 萲・國分修一：薄層鋼織維補強コン クリート舗装による路面改良の実施例, 舗装, Vol. 15, No. 5,1980 年.

7) Design of concrete overlays for pavements, ACI comittee 325, Journal of ACI, Aug., 1967.

8) Guide to concrete resurfacing designs and selection criteria, publication EB 087,01 p, Portland Cement Association, 1981.

9) Hannant, D. J. : Fibre cements and fibre concretes, John Willey \& Sons, pp. 182 197, 1978.

10) Westergaard, H. M. : Stress in concrete pavements com puted by theoretical analysis, Public road, Vol.7, No. 2,1926 .

11）福田 正：コンクリート舗装の荷重分散機構に関する研 究，土木学会論文報告集，No. 242，pp. 63 72, 1975 年.

12) Finn, F. N. : Factors involved in the design of asphaltic pavements surfaces, Highway Research Board, National cooperative highway research program report 39 , pp. 6 24, 1967.

13) Yoder, E. J. and Witczak, M. W. : Principles of pavement design, John Willey \& Sons, pp. 269 272, 1975.

14) Meyerhof, G.G. : Load-Carring capacity of concrete pavements, Journal of the soil mechanics and foundation division, ASCE, Vol. 88, SM 3, pp. 89 116, June, 1962.

15) Losberg, A. : Pavements and slabs on grade with structurally active reinforcements, Journal of ACI, Vol. 75, pp. 647 657, Dec. , 1978.

(1983. 8. 31 • 受付) 